\title{
The Function of Criminal Law Enforcement in The Discretion Of Police Of Republic Of Indonesia
}

\author{
Yose Indarta \\ \{yoseindarta.s2stin@gmail.com\} \\ Doctor of Law, Universitas Jayabaya, Jakarta, Indonesia
}

\begin{abstract}
The discretion of the police in the enforcement of criminal law emphasizes on the need to treat humans as human beings, to respect their self-esteem and to conform with Pancasila as the basic law and philosophy of Indonesia. Pancasila contains the command to protect humans by preventing arbitrary actions and creating fine society. This normative legal research was done using statutory, conceptual, historical, and analytical approaches, and used primary, secondary and tertiary legal materials. Data were collected by sorting out and classifying legal materials, making inventory, classification, and adjustment to the problem to allow comprehensive analysis. The results of the research showed that the discretion of the police in enforcing criminal law must be philosophically accounted for in this constitutional state based on the objectives of law enforcement and legal responsibility as mentioned in the laws and regulations: The Police Law, the Adpem Law, and / or Perkapolri concerning Police Professional Code of Ethics, as well as external accountability: occurs from the exercise of authority. The action can be performed by separating personal matters of police members or police investigators. It is also necessary to determine whether it is the responsibility that follows police 's position or the responsibility that follows official / private matter, either through the general court or the State administrative court. Therefore, the law enforcement can be normatively accounted for according to the police law as its legitimacy and the Criminal Procedure Code as its operational aspect.
\end{abstract}

Keywords: Discretion; Law enforcement; Police

\section{Introduction}

Juridically, police discretion is enshrined in Law Number 2 of 2002 concerning the Indonesian National Police (State Gazette of the Republic of Indonesia of 2002 Number 2, Supplement to the State Gazette of the Republic of Indonesia Number 4168, from now on referred to as the Police Law). Discretion is interpreted as freedom to act or decide. However, the freedom is limited. Sjachran Basah says that the limitation entails the upper and the lower limit [1]. Likewise, according to Muchsan, the first limitation is that it must not conflict with the prevailing legal system (positive legal principles) and only for the public interest.

The existence of police discretion is based on the Police Law, especially in law enforcement, and Law Number 8 of 1981 concerning Criminal Procedure Law (State Gazette of the Republic of Indonesia of 1982 Number 76, Supplement to the State Gazette of the Republic of Indonesia Number 3209 after this referred to as Criminal Procedure Code) [2]. Although investigations and inquiries are regulated in the Criminal Procedure Code, there are 
still many gaps that accommodate the opportunities for discretion. This includes the existence of Article 5 paragraph 1 sub a point 4 of the Criminal Procedure Code and Article 7 paragraph 1 letter $\mathrm{j}$ of the Criminal Procedure Code, which both state: yield actions in accordance to accountable law and provide an opportunity to implement a policy of acting for the investigators based on personal considerations [3].

In general, the police members, especially the investigators at the Reserve (Criminal Investigation Agency), have implemented discretions that vary in quantity and quality. The types of action that are most often applied are in the form of [4]:

a. actions related to the arrest, detention, and suspension of detention

b. actions related to misdemeanours by alternative means outside the law

c. actions related to juvenile matters

d. actions related to inspections, especially among officers

e. search

In addition, the Criminal Procedure Code also has other discretional provisions, some of which are:

a. Subjective conditions for detention by an investigator, namely in the event of a situation that raises a concern that the suspect or defendant will escape, tamper, or remove the evidence and/or repeat the criminal act

b. Investigators' authority to take the first action at the scene of the incident

c. Investigators' authority to transfer one type of detention to another.

d. Examination by investigator due to proper and reasonable reason to the residence of the suspect or witness

However, some actions or conduct of investigations are only based on police regulations, which are not regulated in the Criminal Procedure Code or the Police Law [5]. Consequently, due to the power of discretion among the police, especially for the investigators in their function at the criminal law enforcement, this authority lacks effective monitoring and accountability facilities [6]. The Criminal Procedure Code does provide pretrial as a means of control and supervision of coercive attempts by law enforcers, especially police investigators. In practice, however, it does otherwise [7].

When there is an abuse of authority, injustice, corruption, and other negative consequences in police discretion among the criminal law enforcement function, the law should answer these problems. The law aims to prevent malpractices of police discretion that may harm the community or even dishonour the police institution itself, hence distorting the state's authority, especially in enforcing criminal law. This means that the law must ensure that police discretion is following the meaning and purpose of the discretion itself and in line with the concept of a constitutional state. This type of state demands unarbitrary decisions, protection of human rights, the principle of legality, and the existence of an impartial judiciary, including examining state administrators' actions. Law enforcement that is the determining factor and oriented towards protecting human rights and who can be accounted for in line with legal accountability is demanded to be professional [8].

\section{Research Methods}

The research method in this paper is normative legal research with statutory, conceptual, historical, and analytical approaches. The materials were sourced from primary, secondary, and 
tertiary legal materials. The data were obtained by sorting and classifying legal materials. Following this, it is inventoried and classified, and adjusted to the problem to be studied comprehensively.

\section{Results and Discussion}

The function of police discretion in criminal law enforcement is related to the authority and its implementation. Therefore, the concept of accountability discussed here is the responsibility inherent in the authority itself. Authority should meet accountability due to no authority without accountability. (geen bevoegdheid zonder verantwoordelijkheid). As regards the implementation, there is a note about after-action (ex post). There is a difference between a priori action and a posteriori action. The former occurs before the real situation, while the former knows the actual situation after the situation. The latter imposes limits on the action, whether it is following the law or not, and at the same time determines the legal consequences as a system of supervision and accountability. This means that police discretion must be open to the obligation of objective accountability based on its inherent authority and implementation.

The implementation of police discretion in the function of criminal law enforcement is generally seen as involving minor cases as part of the implementation of the repressive function, namely non-judicial repressive, which is not obliged to be reported to the President. There should also the need to impose accountability according to Article 1 number 14, Article 9, and Article 10 of the Police Law as an inseparable part and the implications of internal responsibility that are inherent along with the discretionary powers of the police itself. It should be held accountable to the police hierarchy in their respective jurisdictions. It starts from the district police chief to the city police chief and then to the regional police chief. The regional chief is responsible to the national police chief, of whom he or she is in charge of carrying out police functions such as duties and responsibilities concerning police operational activities and organizing the capacity building of the Indonesian National Police. The national police chief has to report to the President, as stipulated in Article 8 of the Police Law.

However, the accountability of the national police chief as the organizer of the national police and the discretionary accountability of the police in the criminal law enforcement function is not regulated and not clearly stated. Therefore, to reduce the negative impact on discretion for the amelioration of the police profession must follow these principles of authority: accountable authority and no authority without accountability (geen bevoegdheid zonder verantwoordelijkheid). For this reason, it is necessary to regulate and clarify the accountability of the Chief of Police and the whole national police units concerning the use of discretion to exercise their function as criminal law enforcers.

Internal accountability is attached with the discretionary powers of the police itself and external accountability, and it includes in the category of retrospective responsibility, or the actions that have occurred and all their consequences. The police discretion is within the limits of the legal provisions: the hole in the donut. It shares boundary with the law and legislation so that its capability narrow. With that, the discretionary power of the police will not only avoid subjectivity, arbitrariness, and abuse of authority, or maybe, undesirable behaviour. It can also be accounted for based on the concept of constitutional state and law enforcement, which is oriented towards the service of citizens. The boundary also provides legal certainty of the Police Law and the Indonesian Criminal Law Procedure (Kitab Undang-Undang Hukum Acara Pidana-KUHAP) as a juridical consequence. Police Law functions as its aspect of legitimacy, 
and the code as its operational aspect. Conversely, suppose the discretion of the police and its investigators cannot be controlled (uncheckable) or cannot be judged to be tested (unreviewable). In that case, it is contradictory to the conception of the constitutional state and law enforcement itself. It can even be considered tyranny.

Such construction is in line with the principle of participation as part of the principles of the police that demand legal responsibility for every police force member in criminal, civil, or administrative law. It is a guide for implementing police duties that are embraced globally It is a fundamental moral responsibility towards a society that concerns human rights. Therefore, according to Krisna Djaya Darumurti, if government agencies or officials such as the police and their investigators are truly aware of the nature of discretion, then exercising discretion is a delicate matter. When the use of discretion is required, it must be able to explain adequately, and the choice to do so is unavoidable. There has to be a reason for such actions and conformity with general legal principles to make their discretion valid.

In this way, the discretion of the police in general and in particular opens to be held accountable. It is in line with the development of the concept of government discretion that has been accepted for examination by the Administrative Court (Pengadilan Tata Usaha NegaraPTUN) based on Article 53 paragraph (2) letters a and b of Law number 5 of 1986 jo. Law number 9 of 2004 states that the political law paradigm realizes a general system in administrative justice by extending the authority to grant complete legal control over government actions (including actions taken by Government Officials or anyone authorized by law to execute government functions), namely actions of State administrators outside the formation of laws and the implementation of the judiciary.

Based on the perspective of the principle of constitutional state and Pancasila law, which requires legal action (bestuurhandelingen), police investigators as government officials must be held accountable as a form of protection and respect for human rights. This is done by referring to the principle of functional differentiation in the Criminal Procedure Code (Kitab Undangundang Hukum Acara Pidana-KUHAP). It aims to separate those that have been limitedly designated as pretrial objects and beyond what has been regulated in a limited manner through the concept of general administrative law placed in the Government Administrative Law, which falls into the domain of Administrative Court (Pengadilan Tata Usaha Negara-PTUN). It applies the lex posterior derogat legi periori principle, that is, the provisions of the new statutory regulations repeal older statutory.

It is in line with the concept of the constitutional state, especially regarding the existence of a free and impartial judiciary to assess government actions. It is immaterial whether they violate the law (onrechtmatige overgheidsdaad), regardless of whether it is a state administrative court or other judiciaries as the main and universal characteristic of a Constitutional State, or specifically in administrative justice, both administrative moot court (administratiefsberoep) and pure administrative court (rechtsspraak).

\section{Conclusion}

The discretion of the police in enforcing criminal law must be accounted for philosophically according to the constitutional state of law. It is in line with the objectives of law enforcement and must be following the concept of legal responsibility, which is divided into internal accountability according to the provisions of laws and regulations. The internal accountability comprises legal, institutional bodies such as Police Law, the Government Administrative Law, 
and/or the National Police Chief Mandate (Peraturan Kepala Kepolisian Republik IndonesiaPerkapolri) on Police Professional Code of Ethics. Its external counterpart comprises accountability of authority by breaking down and separating the quality of personification quality of police members or the investigators and whether it is the responsibility of the position or the responsibility of an official/individual, either through the public or the State administrative court. Thus, according to the police law, it can be accounted for in a normative manner as its legitimacy. It is also accounted for in the Criminal Procedure Code as its operational aspect.

\section{References}

[1] Nomenson Sinamo, Hukum Administrasi Negara, Jakarta: Jala Permata Aksara, 2014.

[2] Fachmi, Kepastian Hukum Mengenai Putusan Batal Demi Hukum Dalam Sistem Peradilan Pidana Indonesia, PT. Ghalia Indonesia Publishing: Bogor, 2011.

[3] Adrianus Meliala et.al, Diskresi Kepolisian: Dalam Tinjauan Hukum dan Implementasinya di Lapangan, Komisi Kepolisian Nasional, Jakarta, 2013.

[4] Luhut M. P. Pangaribuan, Hukum Acara Pidana: Memberi Keadilan Dengan Tetap Memastikan Kemanusiaan Manusia Melalui Pengendalian Kekuasaan, dalam Shidarta dan Jufrina Rizal, Pendulum Antinomi Hukum: Antologi 70 Tahun Valerine J. L. Kriekhoff, Genta Publishing: Yogyakarta, 2014,

[5] Ronny Lihawa et al, Profil Kinerja Kepolisian Negara Republik Indonesia: Studi Kasus di 24 Polsek (Lampung, Yogyakarta, Nusa Tenggara Barat), Kompolnas, 2010.

[6] Krisna Djaya Darumurti, Diskresi: Kajian Teori Hukum, Yogyakarta: Genta Publishing, 2016

[7] Kadar Slamet, Perluasan Wewenang Mengadili Peradilan Administrasi Terhadap Tindakan Pemerintah, Universitas Katolik Parahyangan, Bandung, 2013. 